\title{
THE SHAFTS OF STRIFE AND WAR: A CRITICAL ANALYSIS OF THE IMMIGRATION (MASS ARRIVALS) AMENDMENT BILL
}

\author{
Christopher Foulkes*
}

This article critically analyses the Immigration (Mass Arrivals) Amendment Bill 2012 currently before Parliament, which purports to deal with the potential mass arrival by sea of asylum seekers. The article first sets the legislation in its domestic and international law context as well as empirically comparing the changes with those recently enacted in Canada and Australia. The purported purposes of the legislation are examined by the article and it is seen that each of these are fraught with legal difficulties. Four major substantive changes the Bill would introduce are then outlined. In relation to the purposes of the legislation, New Zealand's domestic and international legal framework, and in comparison with similar regimes in Australia and Canada, this article concludes that the proposed New Zealand legislation is questionable in terms of both purpose and likely efficacy.

\section{INTRODUCTION}

The appropriate policy response to the mass arrival of asylum seekers came sharply into focus in certain commonwealth legislatures in 2012. In New Zealand, the Transport and Industrial Relations Select Committee recently reported back to Parliament on the Immigration (Mass Arrivals) Amendment Bill 2012 (New Zealand Bill or Bill). ${ }^{1}$ The Bill suggests several major changes to New Zealand's refugee and immigration regimes. This article first outlines the relevant international law, New Zealand's domestic legislative context and the relevant elements of the status quo, as well as the situations in Australia and Canada. It then explains the changes proposed by the New Zealand Bill. In analysing these changes the article looks at the stated purpose of the Bill before turning to critically examine four of the major changes the Bill introduces. The analysis addresses the legal

* Graduate of Victoria University of Wellington Faculty of Law, 2012. I would like to thank Caroline Sawyer, Junita Douglass, and Kathryn Scott-Dowell for their comments.

1 Immigration (Mass Arrivals) Amendment Bill 2012 (16-2). 
effect of the changes and how they interact with the rest of New Zealand's legal framework, and also compares the changes to the legal responses in Canada, where the Protecting Canada's Immigration System Act was enacted earlier in 2012; ${ }^{2}$ and Australia, where the Federal Parliament passed the controversial Migration Legislation Amendment (Regional Processing and Other Measures) Act in August 2012. ${ }^{3}$

All of the major changes proposed by the New Zealand Bill raise legal difficulties and do not necessarily serve the purported purpose of the Bill. Given New Zealand's unique geographical context and the historical lack of mass arrivals, it must be asked whether it is good practice to formulate legislation by adopting a collection of dubious and abandoned policies from other jurisdictions, as appears to be the case with this Bill.

\section{NEW ZEALAND CONTEXT AND STATUS QUO IN RELATION TO MASS ARRIVALS}

To set New Zealand's proposed legislation in context it is important to examine the circumstances of its introduction. The Minister of Immigration, the Hon Nathan Guy, announced the Bill's impending introduction in late April $2012 .{ }^{4}$ Mr Guy claimed that "[t]he recent events in Darwin show that New Zealand is a target for dangerous and illegal mass arrivals by boat. ${ }^{5}$ From the outset, this article maintains that, in fact, New Zealand faces little threat from a mass arrival by boat. There has never been a recorded incident of this and commentary on the current Bill generally accepts that a mass arrival is highly unlikely. With this in mind, the article approaches the current Bill with caution. It seems unclear what actually motivates the legislation. While problems with the purported purposes of the legislation are raised, this article does not speculate what the genuine motivation behind this legislation might be.

Given that the chance of a mass arrival is so slim, it is hardly surprising that New Zealand currently has no special legislative provisions for such an arrival. In this sense, it could be argued that rather than amend a current policy, the Bill actually fills a legislative gap. If there were a mass arrival, presumably New Zealand's current immigration laws, which deal with arrivals individually, would apply. There are four relevant elements of these laws, reflecting the four major legislative changes proposed by the Bill.

2 Protecting Canada's Immigration System Act SC 2012 c 17.

3 Migration Legislation Amendment (Regional Processing and Other Measures) Act 2012 (Cth).

4 Hon Nathan Guy MP "New Measures to Deter People Smugglers Announced" (press release, 30 April 2012).

5 Ibid. 


\section{A Warrants and Detention}

Under the current system, if there is an irregular arrival the relevant legislation only conceives of dealing with each arriving individual independently. ${ }^{6}$ An immigration officer may apply to a District Court judge for a warrant of commitment, which allows for detention of up to 28 days, if: the arrival has not supplied sufficient proof of their identity $;^{7}$ there is not a suitable craft leaving New Zealand for them to be turned around in ${ }^{8}$ they constitute a security risk $;{ }^{9}$ or their detention is in the public interest. ${ }^{10}$ These arrest and detention provisions apply equally to asylum seekers as they do to illegal migrants. The Immigration Act 2009 states only that recognised refugees cannot be deported; ${ }^{11}$ it gives no protection to asylum seekers regarding detention.

\section{B Ability to Judicially Review Immigration Decisions}

The next relevant feature of the current law in New Zealand is the availability of judicial review to those subject to a decision of Immigration New Zealand. The current situation in New Zealand is similar to most government actions and decisions: the High Court has inherent jurisdiction to review a decision of an immigration officer. The only fetter placed on that jurisdiction is that an applicant must apply to have a decision judicially reviewed within 28 days of being notified of the decision. ${ }^{12}$

\section{Government's Role in Refugee and Protection Processing}

The third set of current laws relevant to this article relates to the Government's ability to intervene in, or prolong, the process for claiming refugee status and protection. Under the current provisions a refugee and protection officer is obliged to independently determine whether a claimant falls under the legislative definition of a refugee. ${ }^{13}$ While the Minister of Immigration is granted some regulation-making power under the Immigration Act, ${ }^{14}$ this does not include the power to intervene in or suspend refugee claims.

\footnotetext{
6 Immigration Act 2009, pt 9.

7 Immigration Act, s 317(2)(d).

8 Immigration Act, ss 317(2)(a) and 317(2)(b).

9 Immigration Act, s 318.

10 Immigration Act, s 317(3).

11 Section 129(2).

12 Immigration Act, s 247.

13 Immigration Act, s 137.

14 Section 400
} 


\section{Consequences of Refugee Status}

As noted above, the major consequence of refugee status is that a refugee cannot be deported. ${ }^{15}$ However, the Immigration Act 2009 makes provision for the cessation or removal of refugee status if a person no longer meets the Act's definition of a refugee. ${ }^{16}$ The relevant point to note here is that current policy states that as soon as refugee status is established a refugee is eligible to apply for permanent residence. ${ }^{17}$ Five years after residence is granted, as with all permanent residents, refugees are eligible to apply for New Zealand citizenship. ${ }^{18}$

\section{INTERNATIONAL LAW CONTEXT}

It is important to provide further context by way of discussion of the relevant international law in this area. While the article deals with numerous different facets of international law, the law relating to refugees and asylum seekers is the most contextually relevant. The analysis below highlights that proposed New Zealand legislation is premised on the assumption that a mass arrival would be of asylum seekers who would then claim refugee status. For all three jurisdictions examined, the international law in this field is the same. New Zealand, Australia and Canada are all parties to the Convention relating to the Status of Refugees 1951 (Refugee Convention or Convention) and its 1967 Protocol, ${ }^{19}$ which is the major convention regulating the treatment of refugees and asylum seekers. To various extents, each of the three jurisdictions in question has incorporated the Refugee Convention into its domestic legislation. ${ }^{20}$

There are two major elements of the Refugee Convention that are relevant to this article. First, the Convention defines a refugee. The definition includes people who are outside the State from which they are claiming refuge and who have a well-founded fear of being persecuted for reasons of race, religion, nationality, membership of a particular social group or political opinion. ${ }^{21}$ What is relevant to this article is that the Convention does not make a distinction between people who claim refugee status at United Nations High Commission for Refugees (UNHCR) camps and those who claim directly with individual States.

15 Immigration Act, s 129(2).

16 Section 143.

17 Immigration New Zealand Operational Manual (Wellington, 2012) at [3.10].

18 Citizenship Act 1977, s 8.

19 Convention relating to the Status of Refugees 189 UNTS 150 (opened for signature 28 July 1951, entered into force 22 April 1954) [Refugee Convention]; Protocol relating to the Status of Refugees 606 UNTS 267 (opened for signature 31 January 1967, entered into force 4 October 1967).

20 Immigration Act 2009 (NZ), sch 1; Immigration and Refugee Protection Act SC 2001 c 27 (Canada), pt 2; Migration Act 1958 (Cth), s 91

21 Article 1A(2). 
Second, the Refugee Convention ascribes those with refugee status a series of rights. These include: the right not to have restrictions placed on movement other than necessary ones; ${ }^{22}$ the right not to be expelled save for reasons of national security or public order; ${ }^{23}$ and the right to have the State, as far as possible, facilitate the refugees' assimilation and naturalisation. ${ }^{24}$ The rights associated with refugee status under the Convention do not come into existence only when a State officially recognises someone's status as a refugee, but are inherent to all those who meet the criteria for refugee status. As such, asylum seekers who have not yet had their refugee status established should be granted the same rights as refugees until such time as it is determined that they are not, in fact, genuine refugees.

\section{AUSTRALIAN AND CANADIAN IRREGULAR ARRIVAL REGIMES}

For comparative purposes, it is also necessary to briefly outline the domestic law situations in Australia and Canada before beginning any critical analysis. These countries have been selected because, like New Zealand, they are coastal common law jurisdictions and have both recently confronted the issue of mass arrivals by boat. Thus, the New Zealand Government can look to the experiences of policy-makers in Australia and Canada and draw lessons from them. However, as explained throughout, New Zealand's geographical and historical context is not precisely the same as that of Canada or Australia and this should be borne in mind when comparing the jurisdictions.

\section{A Canada}

In Canada, the Protection of Canada's Immigration System Act (Canadian Act) received royal assent on 28 June 2012. The legislation stemmed out of "a large and growing wave of unfounded asylum claims particularly coming from the European Union", 25 and it purports to strengthen Canada's fight against people smugglers and provide for expediting the processing of refugee protection claims. ${ }^{26}$ Another event that possibly spurred the Canadian Government to introduce the legislation, and one much focused on by proponents of the New Zealand Bill, ${ }^{27}$ was the August 2010 arrival of the MV Sun Sea from Thailand with 492 Sri Lankan asylum seekers on board. ${ }^{28}$ As discussed below, this is relevant to the New Zealand situation because New Zealand's Minister of

\footnotetext{
22 Article 31(2).

23 Article 32(1).

24 Article 34

25 (29 May 2012) 129 CAPD 1020.

26 Protecting Canada's Immigration System Act, Summary.

27 Immigration (Mass Arrivals) Amendment Bill (16-1), General Policy Statement; (3 May 2012) 679 NZPD 1950 .

28 "MV Sun Sea Tamil smuggling suspect arrested" CBC News (online ed, Canada, 5 April 2012).
} 
Immigration considers that "[i]f people-smugglers can reach Canada, they can certainly reach New Zealand."29

The Protecting Canada's Immigration System Act 2012 is omnibus amendatory legislation that amends the Immigration and Refugee Protection Act 2001 by providing for detention of groups designated as irregular arrivals for up to one year, ${ }^{30}$ and grants no rights of appeal to those so designated. ${ }^{31}$ The legislation also: prevents designated groups from applying for permanent residence for at least five years after their designation; ${ }^{32}$ expands the scope of the crime of human smuggling, ${ }^{33}$ provides a minimum sentence for smuggling $;{ }^{34}$ and increases penalties for failing to provide information before entering Canadian waters. ${ }^{35}$

\section{B Australia}

The situation in Australia is less clear-cut. Asylum policies have a long and controversial history and were the subject of a political and legislative deadlock within the Federal Parliament for much of 2012. However, both of Australia's major political parties support certain pre-existing elements of the country's policy. These include: the exclusion of Australia's island territories from its "migration zone" so that refugee claims cannot be made unless asylum seekers reach mainland Australia; ${ }^{36}$ and the mandatory detention of all people arriving in Australia irregularly, pending deportation or resolution of their status. ${ }^{37}$ Mandatory detention applies to asylum seekers as well as migrants illegally in Australia. Both major parties also accept the limitations placed on review of this detention as appropriate. The Australian Human Rights Commission has described these limits as making detention "automatic, indeterminate, arbitrary and effectively unreviewable". ${ }^{38}$

Even when it comes to the most controversial elements of the Australian asylum policy - the type and location of processing which asylum seekers should be subjected to - both major parties agree that onshore processing is not a viable option. Until August 2012, the Government preferred

29 (3 May 2012) 679 NZPD 1950.

30 Immigration and Refugee Protection Act, ss 55(1) and 55(3).

31 Immigration and Refugee Protection Act, s 110(2).

32 Immigration and Refugee Protection Act, s 11(1).

33 Protecting Canada's Immigration System Act, ss 41-46.

34 Ibid.

35 Protecting Canada's Immigration System Act, ss 70-77.

36 Migration Amendment (Excision from Migration Zone) Act 2001 (Cth).

37 Migration Act, s 158.

38 Australian Human Rights Commission A Last Resort? National Inquiry into Children in Immigration Detention (April 2004) at 10. 
an asylum swap with Malaysia, ${ }^{39}$ while the opposition preferred a return to offshore processing in the Pacific. ${ }^{40}$ With the Government now accepting the recent Expert Panel on Asylum Seekers' recommendations that the detention centre in Nauru should be reopened, ${ }^{41}$ and agreeing that there should be a mixed model of offshore asylum processing applied, ${ }^{42}$ it seems the deadlock may be at least temporarily broken.

\section{MAJOR POLICY CHANGES PROPOSED BY THE IMMIGRATION (MASS ARRIVALS) AMENDMENT BILL}

Turning now to the changes proposed by the New Zealand Bill, it is initially important to establish what the provisions of the Immigration (Mass Arrivals) Amendment Bill actually do. At the time of writing, the Transport and Industrial Relations Select Committee has reported back on the Bill. While the Committee has recommended minor changes to the Bill, they have not altered any of the major proposals that this article focuses on. The Bill is yet to have its second reading.

The details of the Bill are still liable to change and, as a result, this article focuses on four of the overarching changes envisaged by the current Bill rather than the legislative detail. These are: the introduction of mass arrival warrants; limits placed on the ability to judicially review; enabling the regulatory suspension of refugee and protection claims; and mandating a three-year reassessment of refugee status before granting refugees permanent residence.

\section{A Mass Arrival Warrants and Detention}

One of the most significant proposals made by the Bill is the definition of a "mass arrival group" and the introduction of warrants for such groups. These warrants would allow for the detention of members of a mass arrival group for up to six months. ${ }^{43}$ As noted above, under the current legislation warrants can only be issued on an individual basis and they only mandate detention for 28 days at a time. ${ }^{44}$

The Bill defines a mass arrival group as a group of more than 10 people who arrive irregularly in New Zealand on the same craft or group of craft that is not part of a scheduled international

39 Migration Legislation Amendment (The Bali Process) Bill 2012 (Cth).

40 (25 June 2012) AUPD HR 4381.

41 Angus Houston, Paris Aristotle and Michael L'Estrange Report of the Expert Panel on Asylum Seekers (Australian Government, August 2012); Press Conference with Julia Gillard, Australian Prime Minister (Houston Expert Panel on Asylum Seekers, 13 August 2012) transcript provided by the Office of the Prime Minister (Canberra).

42 Migration Legislation Amendment (Regional Processing and Other Measures) Act.

43 Immigration (Mass Arrivals) Amendment Bill (16-2), cl 12.

44 Immigration Act, s 317. 
service. ${ }^{45}$ On application by an immigration officer, a group warrant can be issued by a District Court judge if the judge deems a warrant to be necessary to: effectively manage the mass arrival group; manage any security risk arising from the arrival; uphold the integrity of the immigration system; or avoid disrupting the efficient functioning of the District Court. ${ }^{46}$

As discussed below, immigration detention immediately raises issues of international law. While not prohibited outright, detention of immigrants raises tensions in international law that are not easily resolved. Strictly, detention for immigration purposes is permitted so long as it is not arbitrary. ${ }^{47}$ The Office of the United Nations High Commissioner for Refugees advocates that detention is "inherently undesirable" 48 and "should normally be avoided". 49

\section{B Limits on Judicial Review}

Another new feature the Bill introduces is a limit on the ability to judicially review any decisions that may be subject to appeal to the Immigration and Protection Tribunal. Only matters for which claimants have already exhausted their rights of appeal can be subject to judicial review. ${ }^{50}$ This change is purportedly intended to streamline the review process. ${ }^{51}$

\section{Suspension of Refugee and Protection Claims}

The third major change examined is the wide-ranging discretionary power the Bill grants to suspend refugee and protection claims for up to six months by simple regulation. ${ }^{52}$ The Bill states that while a claim is suspended there can be no determination as to the status of the claimant by refugee and protection officers. ${ }^{53}$

\section{Policy Proposal: Reassessment of Status}

The final policy change made possible by the Bill that is of interest to this article is not set out in the Bill itself, but would be enabled by the above changes and has been suggested by the Minister of

45 Immigration (Mass Arrivals) Amendment Bill (16-2), cl 5; Immigration Act, s 115(1).

46 Immigration (Mass Arrivals) Amendment Bill (16-2), cl 12.

47 United Nations High Commissioner for Refugees Revised Guidelines on Applicable Criteria and Standards relating to the Detention of Asylum-Seekers (26 February 1999) at [5].

48 Ibid, at [1].

49 United Nations High Commissioner for Refugees Executive Committee Conclusion No 44: Detention of Refugees and Asylum-Seekers A/41/12/Add.1 (1986) at [e].

50 Immigration (Mass Arrivals) Amendment Bill (16-2), cl 10.

51 Immigration (Mass Arrivals) Amendment Bill (16-1), Explanatory Note.

52 Immigration (Mass Arrivals) Amendment Bill (16-2), cl 15.

53 Immigration (Mass Arrivals) Amendment Bill (16-2), cl 7. 
Immigration. ${ }^{54}$ This is a reassessment of refugee status three years after the initial determination, with permanent residence not granted until that reassessment concludes that the applicant still meets the Refugee Convention definition of a refugee. ${ }^{55}$

\section{REACTION TO THE BILL}

The reaction to the Bill's introduction is indicative of how major a change the proposed amendments would be. From legal and migrant services quarters reaction was swift and almost exclusively negative. While this was to be expected from refugee and migrant advocate groups, the weight of opposition to the Bill from the legal community is notable.

Submissions to the Transport and Industrial Relations Select Committee outright opposed the passage of the Bill, or any suggested major amendments. These submissions were made by prominent organisations such as the New Zealand Law Society; ${ }^{56}$ the Human Rights Commission; ${ }^{57}$ the Human Rights Foundation; 58 the Office of the United Nations High Commissioner for Refugees; ${ }^{59}$ the Auckland District Law Society; ${ }^{60}$ the Wellington Community Law Centre; ${ }^{61}$ JustSpeak; ${ }^{62}$ Amnesty International ${ }^{63}$ and the Ombudsman. ${ }^{64}$

54 (3 May 2012) 679 NZPD 1950; New Zealand Human Rights Commission "Submission to the Transport and Industrial Relations Committee on the Immigration (Mass Arrivals) Amendment Bill 2012" at [44]; Guy, above $\mathrm{n} 4$.

55 Refugee Convention, above n 19, at art $1 \mathrm{~A}(2)$.

56 New Zealand Law Society "Submission to the Transport and Industrial Relations Committee on the Immigration (Mass Arrivals) Amendment Bill 2012".

57 New Zealand Human Rights Commission, above n 54.

58 New Zealand Human Rights Foundation "Submission to the Transport and Industrial Relations Committee on the Immigration (Mass Arrivals) Amendment Bill 2012".

59 Office of the United Nations High Commissioner for Refugees "Submission to the Transport and Industrial Relations Committee on the Immigration (Mass Arrivals) Amendment Bill 2012".

60 Auckland District Law Society "Submission to the Transport and Industrial Relations Committee on the Immigration (Mass Arrivals) Amendment Bill 2012".

61 Wellington Community Law Centre "Submission to the Transport and Industrial Relations Committee on the Immigration (Mass Arrivals) Amendment Bill 2012".

62 JustSpeak "Submission to the Transport and Industrial Relations Committee on the Immigration (Mass Arrivals) Amendment Bill 2012". JustSpeak is a non-partisan network of young people that purports to speak to, and speak up for, a new generation of thinkers who want change in the New Zealand criminal justice system.

63 Amnesty International Aotearoa New Zealand "Submission to the Transport and Industrial Relations Committee on the Immigration (Mass Arrivals) Amendment Bill 2012".

64 Beverley Wakem, Chief Ombudsman "Submission to the Transport and Industrial Relations Committee on the Immigration (Mass Arrivals) Amendment Bill 2012". 
As an aside, the Ombudsman's submission was perhaps the most surprising. Although short, her submission made it clear that the Ombudsman supports the entire submission of the Human Rights Commission and opposes the passage of the Bill. ${ }^{65}$ She claimed that the Bill: has a suspect rationale; possibly breaches New Zealand's international obligations; enables discriminatory policy to be implemented; and potentially imposes unjustifiable limitations on certain New Zealand Bill of Rights Act 1990 (NZBORA) rights. ${ }^{66}$ This is of note because it is very unusual for the Ombudsman, as an Officer of Parliament, to submit to a select committee on issues that do not relate directly to the Official Information Act 1982 - the main relevant legislation she has a legislatively mandated supervisory role over. ${ }^{67}$ Even then, the Ombudsman herself has stated that submission to select committees "should be exceptional."68 However, in this instance the Ombudsman derives her interest from her supervisory function under the Ombudsman Act 1975 and the Crimes of Torture Act $1989 .{ }^{69}$ While still linked to her statutory duties, this could be taken to indicate the Ombudsman's deep concern with the Bill.

\section{CRITICAL ANALYSIS OF THE NEW ZEALAND BILL}

In critically analysing the New Zealand Bill this article first examines the purported purpose of the Bill before engaging in a critical, and comparative, analysis of each of the four major changes the Bill proposes, which are outlined above.

\section{A Purpose of the Bill}

Establishing the overall purpose of the Bill is important for two reasons. First, this is a key first step in trying to gauge the Bill's likely efficacy, as it gives something to measure that efficacy by. Second, establishing the size and scope of the problem to be addressed allows us to assess whether the suggested changes are proportionate. There are multiple purported purposes of the Bill. These include: to combat people smuggling; to prevent "queue jumpers" in the refugee and protection system; and several "streamlining" ancillary purposes.

65 Ibid.

66 Ibid.

67 Official Information Act 1982, ss 28-34.

68 Beverley Wakem and David McGee 2007/2008 Report of The Ombudsmen: Nga Kaitiaki Mana Tangata for the year ended 30 June 2008 (Office of the Ombudsman, 2008) at 11.

69 Wakem, above $\mathrm{n} 64$. 


\section{Purported purpose: combat people smuggling}

Similar to the Canadian legislation, a major purported purpose of the Bill is to combat human smuggling to New Zealand. This is stated in the Bill's General Policy Statement, ${ }^{70}$ and has been repeated by the Minister of Immigration in Parliament, ${ }^{71}$ as well as in his press releases. ${ }^{72}$

Framing the problem that the Bill seeks to address in terms of people smugglers raises three difficulties. Foremost, the type of smuggling the Bill focuses on - mass arrivals by boat - is unprecedented in New Zealand. There are no recorded incidents of the "ongoing risk of a mass arrival of illegal migrants"73 - which the Bill's Explanatory Note speaks of - actually occurring.

However, assuming that New Zealand will one day be faced with the mass arrival of a group of smuggled asylum seekers, legislating to target smugglers may be a prudent move by the Government. In response to this argument, critics of the Bill such as the New Zealand Law Society have argued that New Zealand already has adequate measures in place to combat people smugglers and that the Bill contributes nothing to dealing with smugglers. ${ }^{74}$ New Zealand is a party to the Protocol Against the Smuggling of Migrants by Land, Sea and Air, having ratified it in $2002 .{ }^{75}$ This is the major international instrument designed to combat people smuggling. The crime of human smuggling is also enshrined in New Zealand's domestic legislation, carrying a weighty sanction of up to 20 years' imprisonment. ${ }^{76}$ It would therefore appear that New Zealand does already have several measures in place to combat and prevent smuggling people into the country.

It is also true that the Bill currently does nothing to directly deter smugglers. Unlike the Canadian legislation, the New Zealand Bill does not impose a minimum sanction on people smugglers or expand the scope of the offence. One can only assume that, because the Bill focuses solely on trafficked people and not at all on traffickers, the rationale behind it is that if New Zealand makes being trafficked to this country as unappealing as possible, potential traffickers will be combatted by denying them a customer base.

70 Immigration (Mass Arrivals) Amendment Bill (16-1), General Policy Statement.

71 (3 May 2012) 679 NZPD 1950.

72 Guy, above n 4.

73 Immigration (Mass Arrivals) Amendment Bill (16-1), General Policy Statement.

74 New Zealand Human Rights Commission, above n 54, at [20].

75 Protocol Against the Smuggling of Migrants by Land, Sea and Air, Supplementing the United Nations Convention Against Transnational Organized Crime 2441 UNTS 507 (opened for signature 15 November 2000, entered into force 28 January 2004).

76 Crimes Act 1961, s 98C. 
Unfortunately, the rationale of making being trafficked unappealing and thus denying traffickers a customer base also faces some challenges. In the first instance, common sense dictates that it is unlikely that the proposed changes will be a very effective deterrent. As noted by the New Zealand Law Society: ${ }^{77}$

... it [is] highly unlikely that would-be asylum seekers who are so desperate as to submit to being smuggled would be deterred by the prospect of a longer period in detention or indeed any other of the Bill's measures.

That logic also has the academic backing of UNHCR expert Alice Edwards. ${ }^{78}$

This view is also empirically backed by studies of asylum seekers in mandatory detention in Australia. These studies have shown that detention acts as less of a deterrent than expected, and that the message about detention is generally not relayed to prospective migrants by detained migrants, even when they have the opportunity to do so. ${ }^{79}$

While a purported purpose of the New Zealand Bill is undisputedly to combat people smuggling, the Bill does very little to achieve this. As such, this article examines other purported purposes.

\section{Purported purpose: combat "queue jumpers"}

A part of the Bill's purpose that has been mentioned by the Minister of Immigration, Government members in Parliament, and in the press, is that of combatting "queue jumpers" in the asylum system. ${ }^{80}$ Unfortunately, the view that asylum seekers have somehow "jumped the queue" in front of more genuine and deserving refugees waiting in UNHCR camps to be resettled, misunderstands the international legal instruments that govern the procedure for resettling refugees. The Refugee Convention recognises the legitimacy of claiming refugee status no matter which body receives the claim. ${ }^{81}$ So long as the claimant is outside the State from which they are claiming refuge, it is just as legitimate to claim "a well-founded fear of being persecuted for reasons of race,

77 New Zealand Law Society, above n 56, at [4].

78 Alice Edwards Back to Basics: The Right to Liberty and Security of Person and 'Alternatives to Detention' of Refugees, Asylum Seekers, Stateless Persons and Other Migrants (United Nations High Commissioner for Refugees, Legal and Protection Policy Research Series, April 2011).

79 New Zealand Human Rights Commission, above n 54, at [22]; Vaughan Robinson and Jeremy Segrott Understanding the decision-making of asylum seekers (Home Office Research, Development and Statistics Directorate, Study 243, July 2002); Tetty Havinga and Anita Böcker "Country of Asylum by Choice or by Chance: Asylum-Seekers in Belgium, the Netherlands and the UK" (1999) 25 Journal of Ethnic and Migration Studies 43; Roslyn Richardson "Sending a Strong Message? The Refugee's Reception of Australia's Immigration Deterrence Policies" (PhD Thesis, Charles Sturt University, 2009).

80 Guy, above n 4; (3 May 2012) 679 NZPD 1950.

81 Refugee Convention, above n 19. 
religion, nationality, membership of a particular social group or political opinion"82 directly with a State as it is to claim at a UNHCR camp and wait to be resettled. As researchers at the Australian Federal Parliament have been forced to admit, both are equally entitled to protection. ${ }^{83}$

Further, as the Human Rights Commission points out: ${ }^{84}$

Applying for protection onshore is not a means of "jumping the queue" or bypassing the "correct" process for applying for protection. In fact, applying onshore is the standard and correct procedure for seeking protection under the Refugee Convention.

\section{Ancillary "streamlining" purposes}

The Bill's Explanatory Note also mentions other purposes for which the Bill was introduced, including streamlining the "review process for refugee and protection claims", 85 and the "review proceedings for any matters coming before the Immigration and Protection Tribunal". ${ }^{86}$ However, there is little doubt that these are ancillary and that the entire Bill has been framed as one designed to combat human smuggling.

The Bill runs into difficulties from the outset because its purported purposes either appear to be based on legal misconceptions or appear to not be achieved by the provisions of the Bill. While this article does not question the genuineness of the purposes offered by the Government, it does point out the problems surrounding them.

\section{B Major Changes Proposed}

Assuming the actual purposes of the Bill to be those stated by the Government, the article turns to the major legislative changes suggested by the Bill in order to critically assess them and compare them to the policies in Australia and Canada.

\section{Mass arrival warrants and detention}

The first legislative change examined is the introduction of mass arrival warrants carrying enhanced powers of detention. There are five issues with mass arrival warrants to be discussed: two contextual issues - the model from which the policy was derived and the mandatory nature of the detention; and three substantive issues - the arbitrariness of the detention, whether detention should be used as a deterrent for asylum seekers in the first place, and New Zealand's international

82 Refugee Convention, above n 19, at art 1A(2).

83 Janet Phillips Asylum Seekers and Refugees: What are the Facts? (Department of Parliamentary Services, Background Note, 14 January 2011) at 5.

84 New Zealand Human Rights Commission, above n 54, at [18].

85 Immigration (Mass Arrivals) Amendment Bill (16-1), General Policy Statement at 2.

86 Ibid. 
obligations under the Refugee Convention and the United Nations Convention on the Rights of the Child (UNCROC) ${ }^{87}$ Having canvassed these issues, the proposed changes are compared with, and evaluated against, the positions in Canada and Australia.

\section{(a) Modelling}

The first concern many Select Committee submitters had with the creation of mass arrival warrants and the form they have taken is the model used to formulate policy around the warrants. The Bill's Regulatory Impact Statement was written based on an assumption that 500 arrivals would all claim asylum, with 61 per cent of the claims being declined at the first instance. ${ }^{88}$

There are two points to make about this model. First, if the policy was formulated and evaluated on the basis of there being 500 arrivals - a similar number to the case of the MV Sun Sea in British Columbia - why is the concept of a mass arrival engaged by the arrival of just 11 people? As Amnesty International points out: ${ }^{89}$

If the intention is for the legislation to apply to "mass arrivals" then this should be redefined in accordance with the numbers upon which the calculations in the Regulatory Impact Statement, and other supporting documentation, are based, which is around 500 persons (significantly more than 11).

The New Zealand Law Society echoes this sentiment by asking "[w]hy, if 500 is the typical number involved in a mass arrival, is an arrival of only 11 people sufficient to trigger the proposed detention regime?"90

It does seem incongruous for a policy that has been deliberately calibrated and justified using numbers that would "overwhelm New Zealand's immigration systems" 91 to be engaged by the simultaneous arrival of just 11 people - a number the New Zealand authorities should surely be expected to be able to deal with.

As well as the apparent incongruity between the modelling numbers and the proposed size of mass arrival groups, the wisdom of using 500 arrivals as a model has been generally called into question. While the MV Sun Sea was carrying very nearly 500 asylum seekers, it has been suggested that this is not a reasonable number to use as a model for New Zealand. As the Human Rights

87 United Nations Convention on the Rights of the Child 1577 UNTS 3 (opened for signature 20 November 1989, entered into force 2 September 1990) [UNCROC].

88 John Roseveare Regulatory Impact Statement: Possible changes to legislation and regulations that would apply to any mass arrivals of illegal immigrants in New Zealand (Department of Labour, 2012) at 1.

89 Amnesty International Aotearoa New Zealand, above n 63, at [2.6].

90 New Zealand Law Society, above n 56, at [39].

91 Melanie Webb Advice to the Attorney-General on the Consistency with the New Zealand Bill of Rights Act of the Immigration (Mass Arrivals) Amendment Bill (Ministry of Justice, 3 April 2012) at [22]. 
Commission points out, "a boat carrying asylum seekers has never reached New Zealand's shores. By contrast such boats have arrived in Canada sporadically since the 1970s."92 With a larger sample size, it is more likely that an anomaly like the number of passengers on the MV Sun Sea will arrive. The MV Sun Sea does appear to have been very much an anomaly, at least in the context of vessels departing from Southeast Asia. According to the Human Rights Commission (citing statistics from the Australian Federal Parliament) "[i]n 2010, 4,823 people (including crew) arrived in Australia by boat seeking asylum. There was an average of about 50 people (including crew) per boat. "93

While it is perhaps justified for the Department of Labour to use these more extreme figures to project a worst-case scenario, the Regulatory Impact Statement released to the public withheld the section that would have presumably explained this. The released statement reads: "[r]ecent experience in Canada confirms that a mass boat arrival in New Zealand of up to 500 people is now a real possibility. [Information withheld]." 94 Thus, a proper assessment of the figures used is not possible and this article can only note their decontextualised and anomalous nature as highlighted above.

As to the assumption of only 38 per cent of claimants being granted refugee status in the first instance, while this is analogous to the Australian figures in 2010-2011, these figures were anomalous. In 2009-2010 approximately three-quarters of applicants were granted refugee or protection status in the first instance and in 2008-2009 every applicant was granted refugee status in the first instance. ${ }^{95}$ It seems unfair to use analogous but anomalous figures as the basis for modelling the impact of mass arrivals in New Zealand. Further, looking at only those who were granted refugee protection at the first instance projects an image that the majority of these asylum seekers are not genuine refugees. Further examination of the Australian figures reveals that: in 2010-2011 refugee protection was ultimately granted to 90 per cent of claimants; in 2009-2010 this was 98 per cent; and in 2008-2009 it was obviously 100 per cent. $^{96}$

(b) "Mandatory" detention

The second contextual issue relating to mass arrivals and detention is the nature of the detention. While the Explanatory Note to the Bill as introduced describes it as "mandatory detention", ${ }^{97}$ this is somewhat misleading. In the Australian context, the term "mandatory detention" is used in a way

92 New Zealand Human Rights Commission, above n 54, at [10].

93 New Zealand Human Rights Commission, above n 54, at [11].

94 Roseveare, above n 88, at 3.

95 Australian Department of Immigration and Citizenship Asylum Trends - Australia: 2010-11 Annual Publication (Australian Government, 2011) at 30.

96 Ibid.

97 Immigration (Mass Arrivals) Amendment Bill (16-1), Explanatory Note at 1. 
not suggested by the Bill. Australian law stipulates that mass arrivals in Australia, in fact any irregular arrivals, must be detained until their status has been established or they are deported. ${ }^{98} \mathrm{In}$ the New Zealand context, detention would be contingent on the migrants meeting certain criteria, an immigration officer applying for a mass arrival warrant, and a judge granting that warrant. In this sense, the detention is only mandatory in that once a warrant has been issued the migrant has no discretion as to whether they are detained or not.

However, some Select Committee submitters noted that the detention may end up being de facto mandatory. As the Human Rights Commission put it: 99

The requirements to apply for a warrant of commitment for mass arrival (under a group warrant) are conditions which would inevitably exist in any such arrival. Although drafted as a may [sic] this does not allow for any real discretion and in practice will effectively result in mandatory detention for this group.

\section{(c) Arbitrary detention}

Those contextual issues aside, the article now moves to the substantive issues surrounding detention of mass arrival groups. The first relevant consideration is whether or not the detention is arbitrary. If it is, the new law could be contrary to both New Zealand's domestic legislation ${ }^{100}$ and international obligations. ${ }^{101}$

The Ministry of Justice (MOJ), in its advice to the Attorney-General on the consistency of the Bill with NZBORA, found that detention under the legislation would not be arbitrary. ${ }^{102}$ In making the finding the MOJ alleged "[t]he Bill inserts provisions dealing with the specific situation of a mass arrival of illegal migrants and their detention pending removal."103 The New Zealand Law Society claims that the advice from the MOJ was flawed because, unlike the Regulatory Impact Statement, the NZBORA advice envisions members of a mass arrival group as illegal migrants and not asylum seekers. ${ }^{104}$ While the assumptions by the MOJ were not inaccurate per se, the Government has made it clear that this Bill targets asylum seekers rather than illegal migrants. The

98 Migration Act, s 158.

99 New Zealand Human Rights Commission, above n 54, at [29].

100 New Zealand Bill of Rights Act 1990, s 22 [NZBORA].

101 International Covenant on Civil and Political Rights 99 UNTS 71 (opened for signature 16 December 1966, entered into force 23 March 1976), art 9(1).

102 Webb, above n 91, at [24].

103 Webb, above n 91, at [10].

104 New Zealand Law Society, above n 56, at [48]. 
argument follows that because asylum seekers are not illegal migrants, their detention is arbitrary in that it would be contrary to New Zealand's international obligations under the Refugee Convention.

While the Law Society may be right in saying that the MOJ failed to properly focus on the NZBORA rights of asylum seekers, this would not have necessarily altered the overall advice given. Under the Refugee Convention, which is directly incorporated into domestic legislation by the Immigration Act 2009, ${ }^{105}$ asylum seekers enjoy rights under art 31(2). This article reads: 106

The Contracting States shall not apply to the movements of such refugees restrictions other than those which are necessary and such restrictions shall only be applied until their status in the country is regularized or they obtain admission into another country.

Prima facie, the Bill does not engage art 31(2) as warrants will only be applied for and granted if "the warrant is necessary". ${ }^{107}$ The New Zealand Law Society appears to have overlooked this fact when they claimed that the MOJ's advice is deficient because it "does not consider or even refer to the right to seek asylum or New Zealand's obligations to asylum seekers under article 31.2 of the Refugee Convention." ${ }^{108}$ While it may be true that the MOJ failed to consider art 31(2), had they considered New Zealand's obligations under that article they would have likely found that it did not make the detention arbitrary.

Aside from this, the Law Society makes other valid arguments as to the potential arbitrariness of detention under the new Bill that the MOJ did not consider. The MOJ justified detention as a means to prevent mass arrival groups from "overwhelm[ing] New Zealand's immigration systems". 109 However, with the threshold for a mass arrival group set at more than 10 people, it seems arbitrary to detain 11 migrants in order to prevent them overwhelming the immigration system.

The Law Society also validly claims: ${ }^{110}$

[The Ministry] does not scrutinise the maximum period for which a mass arrival warrant may be sought, despite it being six times that for which existing provision is made under the Act. It lists procedural safeguards (without considering in other than a conclusory fashion their adequacy) but fails to refer to others (such as periodic or detainee-initiated review) that have been removed.

\footnotetext{
105 Schedule 1.

106 Refugee Convention, above n 19, at art 31(2).

107 Immigration (Mass Arrivals) Amendment Bill (16-2), cl 12.

108 New Zealand Law Society, above n 56, at [48].

109 Webb, above n 91, at [10].

110 New Zealand Law Society, above n 56, at [50].
} 
On balance, it is likely that the MOJ was deficient in finding that the detention was not arbitrary for the reasons - other than art 31(2) of the Refugee Convention - outlined by the New Zealand Law Society in their submission.

(d) Detention as deterrent

The question then becomes, what is the purpose behind the detention of mass arrival groups? Here again, there appears to be a dual purpose. First, and least controversially, a group warrant "enables the effective and efficient management of mass arrivals of illegal migrants", ${ }^{111}$ because it is administratively simpler and will prevent any mass arrival group from "overwhelm[ing] New Zealand's immigration systems". ${ }^{112}$ Leaving aside the NZBORA concerns already identified and the fact that the immigration system is very unlikely to be "overwhelmed" by the group arrival of 11 migrants, this purpose may have some justification.

It is the second purpose for detention that is more concerning. In the Minister of Immigration's words, this Bill introduces "tough measures to deter groups of illegal immigrants from travelling to New Zealand." 113 One such measure is detention. Given that it has already been established that the Bill has been modelled on a mass arrival group claiming refugee status, 38 per cent of them successfully in the first instance, it can be assumed that the second purpose of the Bill is to use the disincentive of detention to prevent asylum seekers travelling to New Zealand en masse to claim refugee protection. Questions should be asked about whether this is legitimate.

New Zealand's obligations under international law and the associated jurisprudence appear to suggest that the use of detention as a means of deterring potential asylum seekers is inappropriate. As mentioned above, international law acknowledges that in certain circumstances it might be legitimate to detain asylum seekers. But these circumstances are very limited and clearly prescribed. As highlighted in the Select Committee submission made by UNHCR, there are guidelines issued on the detention of asylum seekers, ${ }^{114}$ and a list of exceptional circumstances under which detention may be permitted. ${ }^{115}$ These guidelines emphasise the fact that detention cannot be justifiable as a "punitive or disciplinary measure" and while not explicitly stating that deterrence should not be a motive, both the UNHCR and the Human Rights Commission posit that using detention as

111 Immigration (Mass Arrivals) Amendment Bill (16-1), Explanatory Note at 1.

112 Webb, above n 91, at [10].

113 (3 May 2012) 679 NZPD 1950.

114 United Nations High Commissioner for Refugees Revised Guidelines on Applicable Criteria and Standards relating to the Detention of Asylum-Seekers, above n 47; Office of the United Nations High Commissioner for Refugees, above $\mathrm{n} 59$, at [44]-[50].

115 United Nations High Commissioner for Refugees Executive Committee Conclusion No 44: Detention of Refugees and Asylum-Seekers, above n 49. 
deterrence is obviously contrary to the spirit of the Refugee Convention. ${ }^{116}$ In the United Nations High Commissioner for Refugee's words from 1986:117

If necessary, detention may be resorted to only on grounds prescribed by law to verify identity; to determine the elements on which the claim for refugee status or asylum is based; to deal with cases where refugees or asylum-seekers have destroyed their travel and/ or identity documents or have used fraudulent documents.

This should be taken alongside the factors already referred to that show detention to be a relatively ineffective means of deterring asylum seekers. ${ }^{118}$

(e) Other international obligations

As well as the Refugee Convention, the Bill's detention provisions also engage New Zealand's obligations under UNCROC. ${ }^{119}$ New Zealand is a party to UNCROC and, while it is not directly incorporated in domestic legislation, the Court of Appeal has dismissed the suggestion that the Minister of Immigration and his department are at liberty to ignore UNCROC, arguing that this would imply that the country's adherence was "at least partly window-dressing". ${ }^{20}$

UNCROC states that detention of children should be used "only as a measure of last resort and for the shortest appropriate period of time". ${ }^{121}$ The Bill would prevent children under the age of 18 from being detained under a mass arrival warrant if they arrived without a parent, guardian, or relative who is also being detained. ${ }^{122}$ However, by logical extension, this suggests that children could be detained if they did arrive with relatives. The limits placed on the ability to detain a mass arrival group are few. Detention is permissible to: effectively manage the mass arrival group; manage any security risk arising from the arrival; uphold the integrity of the immigration system; or avoid disrupting the efficient functioning of the District Court. ${ }^{123}$ As mentioned above, the Human Rights Commission cites a risk that detention will become de facto mandatory for all mass arrivals

116 New Zealand Human Rights Commission, above n 54, at [23]; Office of the United Nations High Commissioner for Refugees, above n 59, at [46].

117 United Nations High Commissioner for Refugees Executive Committee Conclusion No 44: Detention of Refugees and Asylum-Seekers, above $\mathrm{n} 49$, at [b].

118 See Part VII A 1 above.

119 UNCROC, above $\mathrm{n} 87$.

120 Tavita v Minister of Immigration [1994] 2 NZLR 257 (CA) at 265.

121 UNCROC, above n 87, at art 37(b).

122 Immigration (Mass Arrivals) Amendment Bill (16-2), cl 12.

123 Ibid. 
that meet the criteria. ${ }^{124}$ In this sense, detention of children could be used as a first, rather than a last, resort.

\section{(f) Comparative jurisdictions}

Despite the concerns over New Zealand's proposed mass arrival warrants and their detention regimes, these proposals appear to be less problematic than they are in either the Canadian or the Australian systems.

\section{(i) Canada}

Canada has recently implemented a similar regime to that proposed in New Zealand, with group warrants being issued to hold asylum seekers in detention. The Canadian version entails a possibly more arbitrary detention of mass arrival groups. In Canada, a group can be detained for up to 12 months. ${ }^{125}$ It is more difficult to argue that this is administratively necessary than under the six months proposed by the New Zealand Bill. However, there are other elements and safeguards of the Canadian model that have not been suggested by the New Zealand Bill. Significantly, the Canadian legislation does not limit the rights to judicial review of detained migrants, whereas the New Zealand Bill would allow judicial review only after the final right of appeal was exhausted. ${ }^{126}$ While this is discussed in depth below, suffice to say the right of review is a fundamental safeguard against the arbitrariness of any detention.

(ii) Australia

There are many lessons to be drawn from the Australian context. It is important to bear in mind that Australian mandatory detention is distinct from New Zealand's proposed detention in that it is mandatory for all irregular arrivals - not just those subject to a mass arrival warrant - and further, it is not time-limited the way the New Zealand proposal is. However, there are still three lessons that can be taken out of the Australian experience.

The first is that detention largely does not work as an effective deterrent. This has been canvassed above and does not require further explanation. ${ }^{127}$

The second relates to the human cost of mandatory detention. In 2011 Australia saw rooftop protests and riots held at both their Christmas Island and Sydney detention centres in protest at the indefinite nature of detention. These protests caused serious damage to both detention centres with

\footnotetext{
124 New Zealand Human Rights Commission, above n 54, at [29].

125 Immigration and Refugee Protection Act, ss 56-58.

126 Immigration (Mass Arrivals) Amendment Bill (16-2), cl 10.

127 See Part VII A 1 above.
} 
some sections being burnt to the ground. ${ }^{128}$ Questions must be raised about the efficacy and fairness of the detention regime in Australia if the very people who are attempting to claim refugee protection, whose interests it is in to be viewed favourably by the Australian Government, are forced to go to such lengths to protest against their treatment. However, these types of protest are unlikely to occur in New Zealand under a six-month detention regime.

Coupled with this, the health effects of mandatory detention on asylum seekers in Australia have been severe and well-documented. Immigration detention is known to have negative impacts on detainees' mental health, particularly in the case of detained children. ${ }^{129}$ While these risks are obviously concerning from a sociological perspective, they also engage binding international law obligations - particularly when it comes to children - as discussed above. ${ }^{130}$

The final lesson from the Australian experience is that detention is a very costly exercise. The New Zealand Department of Labour dismissed this in their Regulatory Impact Statement. They found that while the overall cost of detention for a mass arrival group of 500 would be around $\$ 17,000,000,{ }^{131}$ the cost of detaining 500 arrivals in the current system under individual warrants would also be around $\$ 17,000,000 .{ }^{132}$

While it may well be true that the two systems have similar costs when dealing with the same group of people, what the Department of Labour failed to factor into their costing was the fact that under the status quo an asylum seeker may only be detained if there is doubt about their identity, if there is an identified threat or risk to security, or in order to facilitate deportation action. ${ }^{133}$ Under the proposed changes, a mass arrival warrant could be issued simply because "the warrant is necessary to effectively manage the mass arrival group". ${ }^{134}$ As a result, if a mass arrival ever occurs in New Zealand it is likely that the Bill would see the Government bear the financial cost of detaining a greater number of asylum seekers than the status quo would. The Human Rights Commission cites Australian statistics that show the 2011 cost of detention came to AUD 137,317

128 Phillip Hudson and others "Extra police sent after Christmas Island detention centre riots" Herald Sun (online ed, Melbourne, 18 March 2011).

129 Zachary Steel and others "Global Protection and the Health Impact of Migration Interception" (2011) 8 PLoS Medicine 1; Australian Human Rights Commission National Inquiry into Children in Immigration Detention, Background Paper 8: Deprivation of Liberty and Humane Detention (2001).

130 UNCROC, above n 87, at art 37(b).

131 Roseveare, above n 88 , at 8 .

132 Roseveare, above n 88, at 6.

133 Immigration Act, s 309(1).

134 Immigration (Mass Arrivals) Amendment Bill (16-2), cl 12. 
per person, whereas the Australian Red Cross estimates the cost of community-based asylum seekers to be AUD 11,248 per year - more than 90 per cent less expensive. ${ }^{135}$

The Government should be cautious about moving towards an Australian-style policy of mandatory detention. This is particularly the case if it cannot be proven that: there are identifiable factors that outweigh the problems this detention would cause with New Zealand's domestic legislation and international obligations; the New Zealand context is sufficiently different to Australia that detention will work as a more effective deterrent; and the human and financial costs of the policy will be lower than they have been in Australia. There is currently no evidence that the Government has, or even can do any of these things.

\section{Restrictions on reviewability}

The second set of legislative changes the Bill proposes are limits on the right to review any decision that has not yet been appealed as far as possible through the Immigration and Protection Tribunal system and has not been granted leave from the High Court. ${ }^{136}$ In analysing these changes, this article examines rule of law issues, NZBORA issues, and practical issues, before comparatively analysing the situations in Australia and Canada.

(a) Rule of Law

Any purported curtailment of the right to go to court carries obvious rule of law issues. In Britain, a similar streamlining Bill came before the House in 2003. That Bill sought to remove the right to apply to have unsuccessful refugee claims judicially reviewed. ${ }^{137}$ The extra-judicial response from British judges to this provision was damning, with Lord Chief Justice Woolf describing the clause as being "fundamentally in conflict with the rule of law." ${ }^{138}$ While New Zealand's proposal does not go as far as the British Bill did - only limiting the right of review and not extinguishing it - the New Zealand Law Society noted in its submission on the Bill: ${ }^{139}$

... any statutory fetter on the right of judicial review necessarily raises rule of law issues. The High

Court's inherent supervisory jurisdiction is the principal mechanism for ensuring that government is carried out in accordance with the law.

135 New Zealand Human Rights Commission, above n 54, at [24].

136 Immigration (Mass Arrivals) Amendment Bill (16-2), cl 12.

137 Immigration and Asylum (Treatment of Claimants, etc) Bill 2003 (UK), cl 11.

138 Lord Woolf "The Rule of Law and a Change in the Constitution" (2004) 63 CLJ 317 at 328.

139 New Zealand Law Society, above n 56, at [66]. 
It is not clear that an attempt to "streamline the review process"140 is a justifiable reason to make a change that prima facie encroaches on the rule of law and which, the Human Rights Foundation posits, "will have the effect of obstructing access to justice". ${ }^{41}$

(b) NZBORA consistency

The restriction on review proposed by the New Zealand Bill may also directly engage the NZBORA. The NZBORA protects the right of every person affected by a determination of any tribunal or other public authority to apply to have that decision judicially reviewed. ${ }^{142}$ Prima facie, placing a fetter on the right of review by requiring the applicant to have first exhausted all rights of appeal appears to engage the NZBORA. In their advice to the Attorney-General, the MOJ found that the restrictions were a justifiable limitation on the right of review as: ${ }^{143}$

[They] remove the incentive to take review proceedings instead of using the normal appeal process.

Appeals under the Act are on points of law only so the issues dealt with on appeal and on review are

likely to be substantially the same.

The MOJ also cited precedent from the Court of Appeal and Supreme Court, who have found "similar provisions"144 are justifiable in the Employment Relations Act $2000^{145}$ and the Tax Administration Act 1994. ${ }^{146}$

However, if the appeal process and the review process are "substantially the same" as the MOJ suggests, this article can see no justifiable reason to limit an asylum seeker's rights to review as protected under the NZBORA. Additionally, as the Human Rights Foundation highlighted in its submission, neither of the provisions cited as having been sanctioned by the Supreme Court or Court of Appeal relate to orders for detention in the way that the proposed changes do. "The right to liberty is given paramount importance under international law and should be considered in a separate light." ${ }^{147}$ In light of this difference, the view of the Human Rights Foundation is that: ${ }^{148}$

140 Immigration (Mass Arrivals) Amendment Bill (16-1), General Policy Statement.

141 New Zealand Human Rights Foundation, above n 58, at [17].

142 NZBORA, s 27(2).

143 Webb, above n 91, at [27].

144 Webb, above $\mathrm{n} 91$, at [28].

145 Employment Relations Act 2000, s 184(1A); Employment Relations Authority v Rawlings [2008] ERNZ 26 at [26] and [36].

146 Tax Administration Act 1994, s 109; Westpac Banking Corp v Commissioner of Inland Revenue [2009] NZCA 24, [2009] 2 NZLR 99 at [61]-[62]; Tannadyce Investments v Commissioner of Inland Revenue [2011] NZSC 158, [2012] 2 NZLR 153.

147 New Zealand Human Rights Foundation, above n 58, at [16]. 
While it is probable that New Zealand courts would declare that this restriction is unjustifiable contrary to the NZBORA, it so obviously restricts access to justice that it should be removed from the Bill.

In this context, it is likely that the limitations on judicial review are inconsistent with the NZBORA.

(c) Practical issues

Issues with the proposed judicial review provisions are not simply abstract. Not being able to initiate judicial review proceedings until after the final right of appeal has been exhausted has potentially negative practical consequences as well. The change would apply equally to aspects of the process that generally are not solvable by appeal, and would: ${ }^{149}$

... preclude an appellant from seeking relief on the grounds of delay in the processing or determination of an appeal to the Tribunal, and also where the Tribunal wrongly declines to determine one or more particular aspects of the appeal.

The clearest examples of where judicial review was required before all rights of appeal had been exhausted were the high profile cases involving Ahmed Zaoui. In these cases, judicial review proceedings: ruled on Mr Zaoui's natural justice right to have information pivotal to the proceedings made available to him; ${ }^{150}$ challenged his continued detention pending determination of a review of his security risk status; ${ }^{151}$ and upheld his challenge to the further involvement of the InspectorGeneral of Intelligence and Security on apparent bias grounds. ${ }^{152}$ Each of these factors either affected Mr Zaoui's immediate situation or affected the information he was entitled to have going into an appeal. In this respect, these factors necessarily were required before Zaoui's final right of appeal had been exhausted.

(d) Comparative analysis

(i) Canada

In passing the Protecting Canada's Immigration System Act 2012, the Canadian Parliament appears to have had as one of their assurances that any decisions taken under the Act would be liable to judicial review. The Government pledged: ${ }^{153}$

148 Ibid.

149 New Zealand Law Society, above n 56, at [61].

150 Attorney-General v Zaoui [2005] NZSC 38, [2006] 1 NZLR 289.

151 Zaoui v Attorney-General (No 2) [2005] 1 NZLR 577 (SC).

152 Zaoui v Greig HC Auckland CIV 2004-404-317, 31 March 2004 per Salmon and Harrison JJ.

153 (26 March 2012) 99 CAPD 1205. 
As an added protection for all claimants, should the IRB [Immigration and Refugee Board] reject their [asylum seekers'] claims, they may still apply for judicial review at the Federal Court. These processes help ensure the fairness and integrity of our refugee system and they would continue to do so if Bill C31 is passed. In fact, most claimants would have access to a new appeals process with the coming introduction of a new independent body, the refugee appeal division, into the refugee system.

It appears that judicial review is not limited to requests being made after an unsuccessful appeal to the refugee appeal division either. The new legislation does nothing to curtail claimants' ability to apply for a review at any stage in the process. This is in stark contrast to the New Zealand legislative proposal, which - in the name of streamlining - places a fetter on the inherent right to apply for High Court review.

(ii) Australia

Compared to the Australian situation in relation to review, the proposed New Zealand position is at least relatively certain. While in theory asylum seekers can apply for judicial review before their final right of appeal has been exhausted in Australia, and can even apply while they are being mandatorily detained awaiting determination of their status, a 2004 Human Rights Commission report into children in the asylum process in Australia found that while judicial review is possible, it is highly exceptional, and: ${ }^{154}$

... throughout the period examined by the Inquiry, Australian law failed to provide effective avenues for the prompt and routine review of the need to detain in the first instance, and whether continuing detention is appropriate.

In this respect, at least in 2004, it seems that the Australian review process was uncertain and often failed to act effectively as a check on government actions. While it is undesirable to fetter the right to judicial review in New Zealand, at least it is clear how and when the right will be able to be exercised.

\section{Suspension of claims}

The third set of changes suggested by the Bill are those relating to the proposed regulationmaking power to suspend refugee protection claims for up to six months. ${ }^{155}$

(a) "Henry VIII" clause

From a public law perspective these powers are inherently dangerous. As the Law Society points out, the proposed provisions represent a "Henry VIII" clause, ${ }^{156}$ which is to say they grant

154 Australian Human Rights Commission, above n 38, at [6.8.3].

155 Immigration (Mass Arrivals) Amendment Bill (16-2), cl 15.

156 New Zealand Law Society, above n 56, at [55(c)]. 
regulatory powers to suspend a process stipulated by an Act of Parliament: ss 129-142 of the Immigration Act 2009. The Law Society is correct in their observation that "it is not good process to authorise the executive to override primary legislation by statutory regulation", ${ }^{157}$ which is what the Bill currently does.

(b) Lack of legislative guidance

Putting aside a public law scholar's inherent distaste for "Henry VIII" clauses, in order to assess the proposed changes, this article must attempt to establish their purpose. The danger of the powers mandated by the provision is heightened by the fact that the Bill offers limited guidance about when regulations should be made to suspend refugee claims. While the Select Committee recommended amending this, at first reading the Bill simply mandated the making of regulations that "specify the claims or types of claims that a refugee and protection officer is suspended from determining". ${ }^{158}$ The Select Committee report recommended a substantive limit be put on the Minister's ability to make regulations in this area by suggesting that the circumstances of the claim should be required to be sufficiently uncertain or liable to change that a "determination or decision ... is unlikely to produce a robust outcome." 159

Looking to Select Committee submissions and the changes recommended by the Committee, the UNHCR submission alleged that government officials explained that the power to suspend a claim would be invoked "where there is a rapidly evolving situation in a country of origin such that it would make an accurate assessment of refugee status difficult." 160

The fear expressed by UNHCR was that leaving the regulation-making power broad and discretionary, and not providing any guidelines for its use, would leave it open to abuse and being used to deter asylum seekers, as the UNHCR concludes it has been in Australia. ${ }^{161}$ To mitigate this risk, the UNHCR recommended: ${ }^{162}$

... that the circumstances under which a suspension of refugee status determination processing may be contemplated, implemented and withdrawn ... should be clearly specified in the principal Act rather than contained in subsidiary regulations.

157 Ibid.

158 Immigration (Mass Arrivals) Amendment Bill (16-1), cl 15.

159 Ibid.

160 Office of the United Nations High Commissioner for Refugees, above n 59, at [62].

161 Office of the United Nations High Commissioner for Refugees, above n 59, at [65].

162 Office of the United Nations High Commissioner for Refugees, above n 59, at [66]. 
This would not only reduce the risk of abuse of the regulation-making power, but it might also satisfy some critics of the "Henry VIII" nature of the powers by stipulating specific circumstances in which provisions of the Act could be suspended by regulation.

The UNHCR's fear appears to have only been partially mitigated by the changes introduced at Select Committee. While criteria have been introduced to fetter the Minister's power, the Select Committee still leaves that power broad. Almost by definition, asylum seekers are fleeing changeable and often war-torn situations and if changeability is the only criterion for suspending the refugee claims of asylum seekers then the Minister is still able to suspend claims almost at will.

The suspension of applications from nationals of specific countries has been identified as discriminatory and violating the right to seek asylum as guaranteed by the Universal Declaration of Human Rights. ${ }^{163}$ While it is acknowledged that the Universal Declaration does not have binding legal status, it is suggested that it is not justified to grant dubious regulation-making power while providing no guidelines as to when regulations should be made, simply for the purpose of "streamlining" the refugee and protection process.. This is particularly the case when those regulations will likely be used discriminatorily and contrary to the Universal Declaration.

It seems that the suspension of a claim would also be exempt from judicial review. By definition, a suspension happens prior to the final right of appeal being used and thus the legislation would oust the High Court's jurisdiction to review such a suspension. This would effectively mean the Minister would be granted the right to suspend a claim for six months despite legislative provisions to the contrary and that decision would be exempt from judicial review.

(c) Comparative analysis

(i) Canada

In comparison to the proposed changes in New Zealand, the Canadian Government's ability to suspend refugee and protection claims is fettered by clear criteria set out in their Immigration and Refugee Protection Act 2001. ${ }^{164}$ This allows suspension only in circumstances of questions being heard in court about a person's ineligibility on grounds of security, violating human or international rights, serious criminality or organised criminality, or a pending court charge for an offence punishable by a maximum term of at least 10 years. These very strict criteria allow for certainty in the refugee protection process and also minimise the risk of abuse by government agencies. This is probably the type of fetter the UNHCR envisioned for the New Zealand legislation.

(ii) Australia

163 Universal Declaration of Human Rights GA Res 217A, Res A/810 (1948) at 71; Office of the United Nations High Commissioner for Refugees, above n 59, at [38].

164 Section 100(2). 
In Australia, the process for suspending refugee claims appears to be similar to that proposed in New Zealand. In April 2010 the Australian Minister for Immigration and Citizenship suspended all refugee claims being processed at the time for Afghani and Sri Lankan claimants because: ${ }^{165}$

Evolving country information from Sri Lanka and Afghanistan is likely to have a significant effect on

the outcome of assessments as to whether asylum-seekers have a well-founded fear of persecution within the meaning of the Refugee Convention.

This is the kind of discretionary power the suspension provisions will grant the New Zealand Government. Interestingly, the Australian Minister for Immigration and Citizenship lifted the freeze on Afghani claimants six months after it was imposed, declaring he now had "enough information to be able to lift that freeze." 166 Questions arise about the motives and policy-making process behind the proposed change in New Zealand. Is it merely a coincidence that both the Australian example and the New Zealand Bill use the period six months? Has New Zealand simply modelled the Bill on the Australian example, or is there a more scientific basis for the proposal?

\section{Reassessment after three years}

The final proposed change is not in the Bill being debated, but has been announced as a policy change that would be enabled by the Bill and that would follow directly after the legislation was enacted. ${ }^{167}$ The Minister of Immigration announced that a reassessment of status three years after the granting of refugee protection would be introduced and only after that would permanent residence be granted to refugees. ${ }^{168}$

The purpose of this policy appears to be to grant refugees a three-year period of residency while their home country stabilises. If, at the end of this period, the circumstances in a refugee's country of origin have improved such that the refugee no longer faces a well-founded fear of persecution for a Convention reason, they will be repatriated.

(a) International obligations

165 Hon Chris Bowen, Australian Minister for Immigration and Citizenship "Suspension on processing of all new applications from asylum seekers from Sri Lanka and Afghanistan" (Parliament House, Canberra, 9 April 2010).

166 Interview with Hon Chris Bowen, Australian Minister for Immigration and Citizenship (Marius Benson, ABC News Radio, 1 October 2010) transcribed by the Australian Department of Immigration and Citizenship Media Centre (Canberra).

167 (3 May 2012) 679 NZPD 1950; New Zealand Human Rights Commission, above n 54, at [44]-[47].

168 (3 May 2012) 679 NZPD 1950. 
This policy change seems out of line with the Government's obligations under legislation. The Refugee Convention has been incorporated into New Zealand's domestic legislation, ${ }^{169}$ and art 34 of the Convention reads: ${ }^{170}$

The Contracting States shall as far as possible facilitate the assimilation and naturalization of refugees.

They shall in particular make every effort to expedite naturalization proceedings and to reduce as far as

possible the charges and costs of such proceedings.

Prima facie, the policy of only granting temporary visas until a reassessment is completed flies in the face of this provision by intentionally extending naturalisation proceedings instead of expediting them.

(b) Purpose of the Bill

This policy change also does not appear to align with the purposes of the Bill. It does not appear to streamline the refugee protection process, if anything making it more cumbersome, and the only way this could be said to target people smuggling is by deterring genuine refugees from coming to New Zealand to claim asylum by not granting them full rights. That would be a cynical abuse of the refugee process in New Zealand and it must be assumed that the Government does not intend that.

(c) Comparative analysis

Comparative analysis of the policy announcement with the two other chosen jurisdictions is particularly insightful when it comes to this policy.

(i) Canada

The Canadian Parliament has used a slightly different means to effect essentially the same proposal. Under s 11 of the Immigration and Refugee Protection Act 2001, as amended by the Protecting Canada's Immigration System Act 2012, any designated person is not able to apply for permanent residency for five years. ${ }^{171}$ This five-year requirement applies to all designated persons, including those found to be refugees. Because the provision requires designated persons who are found to be refugees to apply for permanent residence of their own accord rather than simply requiring their circumstances to be reassessed, the Canadian regime appears to be more out of line with art 34 of the Refugee Convention than the New Zealand proposal.

(ii) Australia

In Australia, the Howard Government's policy of issuing Temporary Protection Visas (TPVs) instead of permanent residence to those qualifying as refugees has striking similarities to the

169 Immigration Act, sch 1.

170 Refugee Convention, above n 19, at art 34.

171 Immigration and Refugee Protection Act, s 11(1.1)(b). 
proposed reassessment policy in New Zealand. ${ }^{172}$ Both policies would grant those falling within the Convention definition of "refugee" a temporary visa for three years and both policies would then reconsider whether the circumstances in the claimant's home State remained such that they still qualified for refugee status. Only after both of these hurdles had been satisfied and the claimant had waited three years in between, would the host jurisdiction grant permanent residence.

The Rudd Government abolished Australia's TPV scheme in August 2008 and replaced it with Permanent Protection Visas and Permanent Resolution of Status Visas. ${ }^{173}$ To explain this change, the Government stated that: ${ }^{174}$

The government is committed to providing fair and certain outcomes for refugees and abolishing TPVs is consistent with the government's commitment to treating asylum seekers fairly and with dignity.

TPVs and THVs [Temporary Humanitarian Visas] were introduced by the previous government to discourage people smuggling activities resulting in unauthorised boat arrivals (UBAs) and to discourage refugees leaving their country of first asylum.

The evidence clearly shows TPVs did not have any deterrent effect. In fact, there was an increase in the number of women and children making dangerous journeys to Australia.

TPVs were always a controversial element of Australia's asylum policy. Not only did they appear to be irreconcilable with the Refugee Convention and not work as an effective deterrent, but also from a sociological perspective, the Australian Psychological Society described leaving refugees in limbo for three years as causing "an unacceptably high rate of mental health problems." 175

Why then, similar to the suspension of refugee claims, has the Minister announced that New Zealand will pursue a policy so similar to one Australia has already attempted and - similar to the suspension of refugee claims - elected to abandon? This is a question this article does not purport to be able to answer, but which does call into question the policy-making process used for this piece of legislation. Is it simply coincidence that two of the major new changes appear to be modelled on abandoned Australian asylum policies? Are the proposed policies actually grounded in in-depth research that the public is simply not privy to?

172 Migration Amendment Regulations 1999 (Cth).

173 Department of Immigration and Citizenship "Abolition of Temporary Protection visas (TPVs) and Temporary Humanitarian visas (THVs) Amendment of Resolution of Status (ROS) visas for current TPV holders" (9 August 2008) <www.immi.gov.au>.

174 Ibid.

175 Australian Psychological Society "Temporary Status Brings About Mental Health Crisis for Refugees" (press release, 10 October 2006). 


\section{Canadian and Australian Features Not Contained in the New Zealand Bill}

There are several features of Australian and Canadian legislation that the New Zealand Bill does not adopt. Notably, the Bill declines to adopt the Canadian legislative provisions that act as a direct disincentive to people smugglers, as discussed above, and the controversial Australian policies of excluding island territories and extra-territorial processing of asylum seekers. While this is worthy of examination, it is beyond the scope of this article and must be left to another author.

\section{CONCLUSION}

New Zealand, like Canada and Australia, appears to be in a state of flux when it comes to its approach to potential mass arrivals of asylum seekers on the boats of people smugglers. The Immigration (Mass Arrivals) Amendment Bill currently before Parliament proposes some major changes to the Immigration Act, which was only rewritten in 2009. Among these amendments is the introduction of group warrants allowing for the detention of mass arrival groups for extended periods of time. This policy does not sit well with New Zealand's international obligations or its domestic law. Empirical evidence from Australia also suggests that it does not work as an effective deterrent. The ability to suspend refugee claims, and the limits placed on the availability of judicial review, while purportedly to streamline the refugee and protection systems, are both policy changes that lack a sound legal basis. Prima facie these policy changes breach rights to natural justice and basic concepts of the rule of law, as well as New Zealand's international obligations to asylum seekers. The Canadian Parliament declined to adopt either of these policies in recent changes and Australia has experimented with both of them but since abolished at least one of them. The threeyear reassessment policy is mirrored in Canada by a five-year stand down period for designated persons to apply for permanent residence and is strikingly similar to the Australian TPV policy done away with in 2008. This policy also appears to undermine New Zealand's commitment to its international obligations, particularly art 34 of the Refugee Convention.

The Immigration (Mass Arrivals) Amendment Bill 2012 purports to solve a problem outlined by the Government that is yet to even eventuate. It proposes four major legislative changes that are all fraught with difficulty and for which there is little empirical evidence available linking them to the purported purposes of the Bill, or proving that they will actually act as an effective deterrent. Thus, the question remains: why has the Government introduced this Bill? It seems there may be an element of "copycatting" behind the Bill which, given New Zealand's unique context and the limited success these policies have had in other jurisdictions, does not appear to be a good way to formulate legislation in this area. 
